\title{
Quotas: A Highway to Power in Egypt... But for Which Women?
}

\author{
Mariz Tadros*
}

\begin{abstract}
Egypt has recently passed a new quota law, reserving 64 seats for women in addition to its 454 member parliament. While the executive regulations were not issued at the time of writing, the political messages conveyed about the quota are highly relevant: for example, additional seats were allocated rather than existing ones shared. This article speculates on whether the quota will challenge power hierarchies within and among parties. While the quota will undoubtedly increase women's representation in parliament, the political configurations of the existing context - a highly authoritarian one - raise questions as to which women are most likely to occupy these seats.
\end{abstract}

\begin{abstract}
1 Introduction
In June 2009, the Egyptian parliament passed a new quota law adding 64 additional seats, for which only women can compete in the 454-seat parliament. Yet up to the time this article was being written, in June 2010, the executive regulations had not been issued, posing a serious challenge for women who wish to nominate themselves, and precluding a critical discussion of the content and nuances of this new legislation. The quota - or what we know about it so far - has generated intense controversy. On the one hand, Mrs Suzanne Mubarak, the First Lady, has said that the 64 seats represent, for Egyptian women, a 'test to prove her abilities to qualify for the parliamentary seat and show her ability to integrate into [the country's] political life' (Al-Akhbar 2010). On the other hand, Gameela Ismail, a leading political party figure in the liberal el Ghad party, has established a movement against the quota, arguing that it was counterproductive to women's rights because it only served as a fast track to parliament for 'Hawanim Garden City' - Cairo's elite. ' The movement, she explained, will aim to mobilise women from the opposition and women's rights activists into fielding women in the forthcoming national elections of 2010 , but not through the women's quota system (Ouf 2010).
\end{abstract}

This article examines the extent to which the type, conditions and context of the quota are likely to reinforce or contest current power hierarchies, with respect to both the political make-up of the country and its gendered political nature. On the one hand, pro-women reforms may be introduced to boost a country's democratic credentials, while on the other hand, measures to reduce its threat to regime stability are also enforced. The conditions of women's poor political representation outlined in this article indicates a pressing need for affirmative action to be instituted, yet the newly promulgated quota is in many ways highly problematic.

The first part of the article sets out the political context in which the quota was born. It describes the main characteristics of the spiralling nature of authoritarian rule in contracting and expanding political space. It then describes historical and contemporary patterns of women's accession to political power in parliament and how government policy has sought to both shape and react to it. The second section questions the extent to which the quota can serve as a form of affirmative action if accompanied with highly inhibitive conditions and enacted in a highly inequitable political environment. The section that follows examines what the quota signifies for political parties and the power struggles within and among them. Finally, the article questions - without offering any conclusive

IDS Bulletin Volume 41 Number 5 September 2010 (c) 2010 The Author. Journal compilation (? Institute of Development Studies Published by Blackwell Publishing Ltd, 9600 Garsington Road, Oxford OX4 2DQ, UK and 350 Main Street, Malden, MA 02148, USA 
conjectures - whether the quota is a pathway for making politics more inclusive and democratic or whether it serves to give authoritarianism in Egypt a more female face. The article is based on qualitative data of a primary and secondary nature collected in the period between September 2009-May 2010 as part of the Pathways of Women's Empowerment programme's work on voice, agency and pathways to women's political empowerment.

\section{Introducing affirmative action in the context of electoral authoritarianism}

Making sense of both the authoritarian nature of the Egyptian regime and the kinds of activism taking place in what has become a highly volatile political space is a challenge for understanding how a policy such as a quota will play out. Egypt can be described as a semi-authoritarian regime. It typically allows for a certain level of political and civil freedoms within contained, controlled degrees, enough to give the semblance of democracy, but not so great as to potentially risk regime destabilisation. In that sense, it continues to be authoritarian in that there is no prospect of rotation of power or a real challenge to the status quo. The 'semi' identifier is attributed to particular elements, or parts thereof, of a liberal democracy that are adapted, to give the impression of being a democratising country (Ottaway 2003). One element of semiauthoritarian regimes, which is critical for giving the semblance to the outside world of a commitment to the principles of liberal democracy, is the holding of elections. The electoral authoritarian regime is one in which:

[E]lections are broadly inclusive (they are held under universal suffrage) as well as minimally pluralistic (opposition parties are allowed to run), minimally competitive (opposition parties, while denied victory, are allowed to win votes and seats), and minimally open (opposition parties are not subject to massive repression, although they may experience repressive treatment in selective and intermittent ways). Overall, however, electoral contests are subject to state manipulation so severe, widespread and systematic that they do not qualify as democratic. (Schedler 2006: 3)

The above reflects the Egyptian political system in which political pluralism exists in a highly inequitable environment in which it is very difficult to contest the hegemonic power of the ruling National Democratic Party, led by President Mubarak. In this context, there are serious question marks as to whether the quota system will in any way challenge the party status quo.

Egypt has seen a level of political activity, in the past five years, that is unprecedented in its 50 years of authoritarian rule, with an ever-rising number of protests held by a very wide array of groups outside Parliament or the People's Assembly. Despite their contrasting and very diverse agendas, one common feature is their contestation of government policy. On the ground, controlled political space is subject to contraction and expansion upon the government's whims. This space has been used by Kefaya [Enough], a political movement opposed to the inheritance of power from President Mubarak to Gamal Mubarak, his son, as well as other emerging movements in opposition to various dimensions of authoritarian rule and increasing poverty. Despite the social justice impetus behind many of these emerging movements, women are hardly visible in political leadership positions.

Women are also acutely absent from formal political office. Women's parliamentary representation has always been consistently less than 10 per cent, even in the short phase when the number of women MPs were at their peak (1979-1984), as Table 1 shows. Since 1979, the situation has grown progressively worse. In the last parliamentary elections of 2005, four women were elected into parliament out of the 125 women who fielded themselves (Zahran 2008: 179). The President, who has the right to appoint ten members of parliament appointed five additional women, bringing the total number of women in parliament to nine out of $454 \mathrm{MPs}$, or 2 per cent of parliament. ${ }^{2}$ In effect, the 2005 parliament had the lowest number of women since 1976, and the lowest number of elected women also since then. All of the five women appointed were then recognised as National Democratic Party members, none had previous political experience or constituency. It is also worthwhile to point out that the majority of women elected or appointed are highly educated, from the white-collar professional background, and come from the upper class and are socially and/or politically very well connected. 


\begin{tabular}{lllll}
\hline \multicolumn{2}{l}{ Table 1 Proportion of women in parliament 1979-present } \\
\hline Year & $\begin{array}{l}\text { Number of women } \\
\text { elected }\end{array}$ & $\begin{array}{l}\text { Number of women } \\
\text { appointed by } \\
\text { president }\end{array}$ & $\begin{array}{l}\text { Total number of } \\
\text { women in parliament }\end{array}$ & $\begin{array}{l}\text { Total percentage of } \\
\text { women in parliament } \\
\text { (\%) }\end{array}$ \\
\hline 1979 (11 Nov-21 April) & 4 & 2 & 6 & 1.6 \\
1979 (23 June) - 1984 & 33 & 2 & 35 & 9.7 \\
$1984-7$ & 35 & 1 & 36 & 7.8 \\
$1987-90$ & 14 & 4 & 18 & 3.9 \\
$1990-5$ & 7 & 3 & 10 & 2.2 \\
$1995-2000$ & 9 & 4 & 13 & 2 \\
$2000-5$ & 7 & 4 & 11 & 2.4 \\
$2005-10$ & 4 & 5 & 9 & 2 \\
\hline
\end{tabular}

Source Compiled from data presented in UNIFEM (EI Sawi 2008: 87).

Universal suffrage was gained in Egypt in 1956 by the newly independent nationalist government. In 1962, the Nasserite government enshrined a new constitution, which set a quota of allocating 'at least' 50 per cent of the parliamentary seats to farmers and workers. The quota for farmers and workers was supposed to empower the emergence of a parliamentary bloc that would represent the 'interests of the majority', in a context in which Nasser had proclaimed a revolutionary government committed to democracy and socialism (Shuman 2000: 6). Despite the transformations that the country experienced in a shift from state capitalism in the 1960 s to an open market economy in the 1980 s to the present, the 50 per cent quota for farmers and workers remains intact. This is significant, in that when the quota for women was first discussed in parliament, there was much objection to the concept of a quota itself on the premise that it violated the principle of equality of opportunity, in spite of its historical precedence for workers and farmers.

In 1979, the Sadat government, keen to show its democracy credentials, introduced a new Personal Status Law that gave women more rights in case of divorce and sought to enforce new restrictions on the practice of polygamy, and a law setting a quota for women in parliament. Law 21 stipulated that the country will be divided into 176 electoral districts, and two MPs will be nominated from each district, with at least one of the two being from the workers and farmers. The exception, set by the law, is in 30 electoral districts, where at least one of the two seats must be occupied by women. In addition, the law granted the President the right to appoint ten members of parliament, of whom two members at least must be women. Several Egyptian writers have pointed to the significance of the quota law being passed in the same year as that which the Egyptian government signed the CEDAW (El Borai 2000).

In 1983, Law 114 annulled the individual voting system by absolute majority and introduced proportional representation as an alternative system. Article 3 of the Law stipulated that there must be at least one woman on each party list, but did not make any specifications regarding her standing on the list. Of the 33 women who made it to parliament in 1979, two were appointed and 31 were elected. However, the overwhelming number of women who were elected were from the ruling National Democratic Party with only two of them from the opposition. Of the 35 who made it into parliament in 1984, again, only two of the seats were gained by the opposition (El Borai 2000: 5). The poor representation of the opposition in parliament points to the limitations of electoral reform to challenge the power bases for authoritarian regimes. As members of the opposition are quick to point out, the conditions of the proportional representation system were highly discriminatory: a party had to win 8 per cent of national votes as a minimum in order to 
win seats in parliament and the party had to field candidates in each electoral district; in electoral districts where a party wins more than 8 per cent, the additional votes do not count. These conditions were set in a context in which the ruling party had unlimited access to government resources, to state-controlled media and where there are severe restrictions on political freedoms (El Naqash 2000).

The party proportional list system came under attack from independent candidates who argued that it discriminates against those who do not wish to join an existing party. The law was referred to the Supreme Constitutional Court which ruled it out as unconstitutional and which also denounced the women's quota as violating the principle of equal opportunities for all citizens. Accordingly, Law 188 of 1986 cancelled the 30 seats for women. The drop that immediately followed in the parliamentary round after that was attributed to the annulment of the party proportional list (El Borai 2000: 6). Among those who were appointed or elected from the period 1987-2000, there was not a single new female opposition or independent figure in parliament (El Borai 2000: 7).

The low representation of women in 2005 was a major embarrassment for the government. Much effort had been put in bringing to the fore women's political representation and yet the number of women who had fielded themselves in the first place was quite poor: 125 out of 5,177 candidates.

In 2007, a series of highly controversial revisions to the Egyptian constitution were passed. Among the changes made was an amendment to article 62 to stipulate: 'The law may also specify a quota for the participation of women in both chambers' (Tadros 2010). The National Council for Women, Egypt's principal national machinery for women, was responsible for the mobilisation of support for making the necessary constitutional amendment and followed through with intense lobbying within the government and within the High Policy Committee of the ruling National Democratic Party to garner support for a proportional party list. Despite the NCW's efforts and use of political clout, the National Democratic Party finally opted for a reserved seat system quota, one which was vehemently opposed by members of all the opposition parties in parliament. Conspicuously absent from these debates was the voice of the women's movement in Egypt.

\section{Women's quota as affirmative action: a possible oxymoron?}

On one level, associating the quota with affirmative action seems somewhat selfcontradictory. The idea behind affirmative action is that it is a fast track pathway to political office: setting aside 64 seats for which only women can compete was intended to enhance their opportunities for claiming political office, since they would not be competing against men. On the other hand, the quota set conditions for winning the elections that are significantly more inhibitive than for candidates fielding themselves for non-quota seats under the conventional electoral law. To what extent, then, can the quota be a fast track, when the pathway is laden with additional electoral burdens? Under the quota law, the size of the electoral district is not the same as the electoral district for citizens competing for non-quota seats. The size of the electoral district or constituency, according to official statements, will be manifold larger for women competing for quota seats compared with women and men competing for non-quota seats. The former may be delineated along governorate lines, while the latter is delineated along a set of villages or a municipality.

The scale of the problem has deepened with the delay in issuing the executive regulations that would define the parameters of the electoral district, and therefore allow candidates to identify their constituency. It is unclear yet how the 64 seats will be divided across the country. Egypt has 29 governorates, so there are two seats for which women will compete in each governorate, amounting to 58 in total. The governorates of Cairo, Beheira and Sharqia, being the largest governorates in terms of population, would each receive two additional seats for which women can compete. Another possible scenario is that rather than designating the entire governorate as the electoral district for which women compete, the executive regulations of the law would designate alternative parameters to the electoral district. How this would be done in a way which bears in mind the drastic differences in population size and would not discriminate in favour of a particular political party in terms of its constituency are details that 
the executive regulations would, in such a scenario, have to explain. Sources say that the executive regulations must come out before parliament breaks for the summer holidays at the end of June.

In view of the large geographic parameters of the electoral district, if the above scenario is enacted in the executive regulation, the quota will be interpreted as a signal that the political pathway to a parliamentary seat is not through the mobilisation of a constituency. One of the women interviewed for this study, a member of the opposition party, pointed out that: ${ }^{3}$

It is not feasible that you gain political recognition and office sufficient to get the whole governorate to nominate you. It is not realistic, nor feasible. It is hard enough to cover a district, whether for a man or a woman.

Shadya Khodeir, a well-ranked member of the ruling party, with over two decades of political experience says that she fears that some of the quota seats will be given to women who are well known media or public figures, but who do not necessarily have a constituency:

If I field myself against a man I know, well I have a standing in sixteen constituency units [that back me up]. Compare this to a woman being brought in by a parachute and telling people that she is a public

figure ... and this is the fear from the next stage, that they bring women media figures, who will take these seats and who have no connection with the people or a constituency.

In such a scenario, in lieu of winning via building a constituency, women may resort to the political backing of the ruling national democratic party or tagging on the governor's office (and therefore being afforded outreach and political power by association) or acquiring significant media outreach or a combination of all. In all cases, the extent to which a non-constituency pathway to office is a legitimate one will be questioned. It is no surprise that one candidate from the opposition party commented: 'In short it is going to be a majlis hawanim [the upper class ladies' parliament]'.

While the quota as a fast track does not mean it is a panacea for all the political ills inherent in any system, nevertheless, it is significant that it was introduced in a context where gender-based forms of biases as well as more general structural biases have worked to undermine women's political representation. The gender-specific factors associated with poor political representation include an increasingly conservative social environment towards women's equality in general. It is also an environment deeply affected and infiltrated by the Saudi-inspired ultra-reactionary Wahabi Islam, and its emphasis on rigid, gender divisions of labour (read: emphasis on women's domestic roles) and power hierarchies (read: the supremacy of men over women). Opponents (men and women) can spread rumours about amoral behaviour of women MPs. In contexts where honour and reputation make women particularly vulnerable to all kinds of social and family stigmatisations, many women, feeling vulnerable, prefer to step down rather than have their familial and social relations affected by the spread of rumours. Moreover, women nominating themselves who are not backed and surrounded by a circle of protégés may also be vulnerable to sexual harassment, threats and intimidation. These factors can all be accommodated if women nominating themselves were firmly and strongly backed by either family/clan/tribe/political party or constituency - or all of these together. Not all women have the social and political capital to withstand these gender-specific forms of harassment.

Structural or contextual inhibitions in the Egyptian political system have also undermined the opportunities of political representation for the majority of Egyptians. They include the allpervasive role of the National Democratic Party in the country's political life, the exercise of vote rigging and other measures, which undermine the integrity of the electoral process itself. Political marginalisation is also salient, on the basis of class, lack of social connections, religious affiliation (i.e. if the person is a member of a religious minority) or political orientation (Muslim Brotherhood members have been exposed to sporadic waves of repression). Moreover, the fact that the ceiling on electoral expenditure is never respected suggests that candidates with an unlimited financial resource base are well positioned to purchase votes - a common phenomenon in many electoral districts.

The financing of election campaigns is gendered in many ways. Several women considering 
running for political office mentioned that male candidates can tap into the family budget to finance their election campaign, but when female candidates do so, it is considered unjustifiable and associated with squandering the family funds. 'Women just don't have the financial independence necessary to spend according to election campaign needs', commented one woman who said that she would only field the elections if the National Democratic Party supported her election campaign costs.

The wide use of thuggery and violence has also intimidated both voters and elected candidates. Soad el Damlawy, who fielded the 2000 elections and lost, attributed her loss to vote rigging and violence: ${ }^{4}$

I was exposed to a lot of violence: they brought the police on horses and with police dogs and the worst [thing] was they brought the women from prison with microphones and they were swearing at the women going into the voting office and harassing them. They prevented my husband from going into the electoral voting booth and prevented people from going in to vote and they tried to stop me and I said I will go inside in spite of you because I am one of the nominees and one of the policemen attacked me with a stick, breaking my finger.

She pointed out that she will only consider entering the 2010 elections if she is backed by the ruling party, who would 'protect' her from exposure to this violence. Many of the prospective women candidates interviewed for this study, who were affiliated to the ruling party, argued that they would only field themselves if they were put forward by the National Democratic Party (NDP); among the reasons cited were: protection from exposure to violence and thuggery, access to a constituency through the party outreach networks, wide publicity and that they would influence the final outcome of the elections.

\section{Quotas transforming party politics?}

The women's quota does not defy, in any fundamental way, the hegemony of the ruling National Democratic Party. According to leading members of all the opposition parties who were interviewed, the National Democratic Party is expected to win the majority of the 64 seats allocated (although all argue that the NDP would have won a majority anyway without the women's quota). Mounir Fakhry Abd el Nour, secretary general of the liberal Wafd ${ }^{5}$ party, argued that in view of the logistical difficulties of covering the exceptionally large electoral district, it is unrealistic to expect true competition or true representation of a constituency. Hence, the kind of political backing needed to win is likely to exceed the abilities of those who do not have the full backing of the government. ${ }^{6}$ Fareeda el Naqash, feminist and head of the women's committee in el Tagammu, argued that while feminists have long been lobbying for the introduction of affirmative action, this was not the kind of measure that was expected. She suggests that the kind of quota that would have been desirable would have been an open proportional list that is unconditional and that would have allowed for both parties and independents to compete. ${ }^{7}$ She added that a quota that puts the focus on the individual allows for individual use of finances, thuggery and violence to garner personal support, whereas a party proportional list system would encourage the citizenry not to vote for a person but for a political party programme:

\section{A party proportional list would not obliterate the importance of individuals and their personal contribution, but would make it secondary to the actual party programme.}

In the Egyptian context where there is a lack of real political party commitment to women in political leadership, the proportional party list would have forced them to redress this internal gender imbalance. The reserved seat system will certainly encourage parties to field women in the bid to win parliamentary seats. However, its transformative impact on the internal party structure is limited, especially as parties are not required to reconsider their existing list of male candidates but supplement them with women. This 'add-on' quota has been criticised by women's organisations for signalling to the public 'that men have incontestably exclusive rights to the original seats, in the present and the future' (Marei 2009: 32). It is believed that despite the internal resistance to the principle of a quota expressed from within the internal political apparatus of the ruling party, they finally conceded to the additional seats option because it does not involve any power-sharing between the predominantly male majority and the women, nor does it pose a real threat to the complex internal patronage system for the allocation of seats and resources to its elite male leadership. 
All political parties' nomination of women candidates has been consistently poor. For the last parliamentary elections of 2005, the ruling National Democratic Party fielded only six women out of the hundreds nominated, the Tagammu leftist party, which is the party most reputed with supporting women candidates, fielded four women and the Muslim Brotherhood and Wafd each fielded one woman (Zahran 2008: 168). None of the women candidates from the opposition won in the elections. Out of the four that won, one belonged to the National Democratic Party, and the three others ran as independent candidates but then joined the ruling party after winning. This reflects the overall trend in the national elections in which the ruling party won only 33 per cent of the vote (145 seats) but became the overwhelming majority in parliament when 166 members who ran as independents joined the NDP, thus giving them 311 seats, representing 71.9 per cent of seats in parliament (Zahran 2008: 156).

The fact that there are only 64 additional seats to contend for nationwide poses a challenge for the ruling party in determining whom among the wide pool of women who have served as rank and file (but who have never really enjoyed much political leadership or power) will be nominated under the quota system in the forthcoming elections. In March 2010, the strains and tensions of trying to predict who will be supported had come to the surface, leading to speculations that parties, in particular the NDP, had deliberately postponed announcing the list of nominees in order to minimise political loss. Competition over whom among the women members of the NDP should be fielded under the quota system is fierce, and those who have not been selected may react to their exclusion in unpredictable ways.

The stakes also apply to other parties. One young prospective female candidate from the Tagammu leftist party argued that the names of the women who will be put forward by her party have yet to be announced because they are probably trying to avert conflict arising between the central headquarters and the party offices at the governorate level over who should be put forward.

The only substantial competition to the ruling party comes from the Muslim Brotherhood, the largest opposition with a populist base that was able to secure 88 seats of the 454 -seat parliament in the last elections of 2005. The
Muslim Brotherhood is a movement that is officially outlawed but in practice tolerated (although subject to waves of security crackdown). ${ }^{8}$ Some female members of the Muslim Brotherhood are active in the religious and welfare services provided through mosques and affiliate welfare-providing organisations. A leading member of the Muslim Brotherhood in parliament pointed out that they are likely to field about 20 women candidates for the quota seats but that in view of the security risks associated with their members fielding elections, not many families will grant permission to their female members to participate in the elections (he pointed out that they, the Brotherhood, ask for the permission of the husband to allow his wife to field the candidate before they back her).

While the quota is neither going to challenge the NDP hegemony over the outcome of the electoral process, or contest the male-biased gender hierarchies within the political parties, it may serve as a bargaining chip between the ruling party and opposition parties in backstage political processes. The idea put forward by some political spectators is that in cases where the electoral districts are claimed by the NDP, 'substitute seats' can be given to the Muslim Brotherhood and a handful of opposition members. Fatma Shoeb, the head of the women's committee at the central headquarters of El Ghad (Future) Party, one of the newly established political parties, argues that the government will seek to give the semblance of being democratic by perhaps allocating 10-15 of these seats to the opposition and hence, the opportunities of having women from the opposition being represented in parliament are going to be higher. ${ }^{9}$

\section{Engendering authoritarianism or beyond?}

While there is a need for affirmative action, the quota falls short, quantity and quality wise, of the aspirations of having an initiative that is able to significantly expand the opportunities for more women to claim political office. The 64 seats represent no more than 11 per cent of parliament, and therefore fall short of the aspirations for at least 30 per cent representation. In terms of the form the quota has taken, in its current context, it is not likely to challenge power hierarchies within parties or among the parties. It is also not likely to challenge gender hierarchies in society or within 
parties in significant ways, despite the fact that it will ultimately increase marginally, women's political representation in parliament. Certainly it is not expected that any form of affirmative action will serve as a panacea for any country's wide array of historical, structural and political discrepancies and inequalities.

One argument put forward in Parliament by the Muslim Brotherhood and others is that if the forms of political repression and corruption prevalent in the system are addressed (reforming electoral law and practice, eliminating violence, thuggery and seeking to control vote purchase), this would in and of itself create an enabling environment for women's political accession of power. This is certainly difficult to test on the ground, however, there are still gender-specific forms of discrimination that would need to be addressed - including affirmative action. Efforts to make the political system more inclusive to women cannot be postponed until authoritarian rule is overturned. If the quota appeared in the form that feminists have long advocated and which the National Council for Women sought to promote - namely, a proportional party list system (with conditions), then at least parties would have been obliged to alter their structures in order for women to claim leadership positions. Yet the rumours about the size of the electorate district have already created a high level of insecurity among women who were considering fielding the elections, even as independents. In that sense, the quota may privilege women who have the financial and political resources to cover wide territories quickly, as opposed to those who have for years built a strong constituency. The latter are more likely to benefit from competing for the non-quota seats.

The quota will increase the number of women in parliament marginally, but it will not address the power inequities that have disadvantaged women who are not affiliated to the National Democratic Party. The NCW has provided training to more than 3,000 women and invited women affiliated to all political parties to participate (a fact that many women from the opposition were quick to confirm).${ }^{10}$ However, its refusal to take on the advocacy of cases of women candidates' exposure to sexual harassment, violence and vote rigging, i.e. the contextual dynamics that make accession to political office prohibitive means that inequities are left untouched. The NCW claims that it does not wish to adopt a partisan position by providing technical assistance to individual candidates fielding the elections, yet without such concerted efforts, there is no way that women from the opposition or who run as independents but lack significant financial and political clout stand a chance of competing.

It is not enough to ensure equality of access to participation when power inequalities are so embedded that by default, interventions will only serve to reinforce the status quo. Two lawyers leading two well-known women's NGOs reported inadvertently contributing to the hegemonic dominance of the NDP in political life through their work to promote women's political agency. One activist pointed out that her organisation was at one point active in helping women in the poor community to issue electoral cards, which are required to enable women to vote in the local council elections, Shura Council (Upper House) or Parliament. The premise behind the work was to increase women's political participation in the country's parliamentarian life until she discovered that in practice it meant more votes being given to the NDP. By virtue of its standing in the community and its ability to use money, favours and promises of services, the NDP was able to secure these women's votes. This may show the weakness of other political parties, but ultimately, this activist was concerned that in the light of the political scene, she did not want to be contributing to its increasing dominance. The other lawyer pointed out that she had sought to strengthen women's activism at the rank and file level within the political parties by providing training on relevant skills, strategising, etc. She went out of her way to invite as many women as possible from the different political parties but in the end she found that the overwhelming majority came from the National Democratic Party - and decided against going ahead with the initiative because of the extreme bias in representation, which she could not overcome. She too did not want to be inadvertently supporting the NDP.

The question is, what kind of affirmative action would contribute most to creating an enabling environment under the current political climate? Certainly, the absence of a strong feminist movement that is able to enter into dialogue with women candidates, political parties and 
other stakeholders significantly undermines the prospects of en-gendering actors and agendas. This article argues that if the projected scenario for how the quota will be implemented comes true: namely the electoral district is defined in terms much larger, then this would be, in many ways, disabling for women, even if they are not competing with men. Under such circumstances, it would make sense for any women candidates who do have strong constituencies on the ground not to field themselves under the quota seats.

Even in electoral authoritarian regimes, there is a high level of unpredictability due to several dynamics, including (a) how external pressures will influence the regime; (b) how the ruling regime will mediate its relationships with various political forces through backstage politics;

(c) the kind of political spaces which are not as controlled which provide 'exceptional' opportunities for gaining ground, and (d) how women candidates' exercise their agency. Each of these will be briefly summarised below.

With respect to the role of external actors, i.e. Western governments, donors, and international civil society organisations, much will depend on whether the quota is celebrated for its proforma nature (especially in view of the regime's efforts to use the quota as a manifestation that it is edging closer towards democracy) or whether there will be scrutiny over which women are able to benefit from the quota. Moreover, the kind of behind the scenes political deals which the regime is likely to try and strike to meet the demands of giving the electoral process sufficient credibility to be taken somewhat seriously while maintaining the status quo, are also likely to produce some unforeseen results, possibly entailing the allocation of particular seats to women candidates from the opposition.

Since electoral 'semi'-authoritarian regimes also afford a degree of political space, there are exceptional cases in which women do reach office by having a long-standing constituency or relying on their family/tribal endorsement or some other context-specific factor without relying on purchase of votes or National Democratic Party support. Finally, there is a certain level of unpredictability in how individual agency is exercised, even in cases where women are expected to tow the party line. For example, Georgette Kalliny, one of the five women appointed in parliament by President Mubarak, is an official member of the National Democratic Party. Yet, she has often taken oppositional stances in parliament against the government (in complete violation of the conventional norms of engagement for other NDP affiliates). Moreover, she openly clashed with the party's leading figure and business tycoon, Ahmed Ezz, over her refusal to back down on her stance calling the government to account for its complicity in the eruption of sectarian classes that took place in Upper Egypt in January 2009. Hence, even the most hegemonic political party cannot guarantee control over MPs' agency all of the time.

\section{Conclusion}

By the time this article is published, the executive regulations are likely to have been published and we will know whether the most flexible or inhibitive interpretation of the law has been advanced. Notwithstanding, it remains that structurally, the quota is neither going to secure 'a critical mass' in parliament, nor is it going to be the highway to power for a critical mass of women from the opposition, or those who have a constituency but not the political clout and capital to substitute for engaging a larger electoral district.

While there is a level of unpredictability in the outcomes of general elections (even in electoral semi-authoritarian regimes), from the prevalent messages conveyed to the public regarding size of electoral district and the number of seats available in a context of ruling party dominance, the quota has already come to be associated with being in line with the existing power dynamics, namely, that the women MPs with the greatest financial, social and political clout are likely to be best positioned to benefit from the new allocated seats. A technical fix through a change of type of quota, namely a proportional representation system would not necessarily be any more transformative, if the conditions accompanying it are inhibitive and the will of the ruling party enacted through the executive and legislative branches of the government continues to prevail. While women cannot wait for a regime change to lobby for greater political representation, there needs to be no illusion regarding the limits of what the current quota can offer, as well as the need for other strategies and pathways of political empowerment to be pursued. Other pathways may include the provision of technical 
assistance and mentoring to all women candidates who are fielding the elections, including those from the opposition and those running as independents. Such support would be sustained throughout the campaigns and if they win, in the stage after that, rather than provided in short phase fashion. ${ }^{11}$ A longer, but essential pathway is to strengthen women's abilities to build relationships with constituencies, even if it takes years. Ultimately, there is a need to capitalise on the media interest in gendered dimensions of politics in order to expose acts of sexual harassment and election misconduct and name and shame those complicit. This would not necessarily transform election practices overnight, but it would put the issue in the spotlight, and if sustained over a long period, may

\section{Notes}

* This research was conducted with the Cairobased Middle East Hub of Pathways of Women's Empowerment. I am very grateful to Dr Hania Sholkamy of the Social Research Center at the American University in Cairo, for her facilitation of this research, her contribution to the framing of the research questions and her constant helpful feedback. I am also very indebted to Sawsan Sherif and Zeinab Ali, senior researchers at the Social Research Center who undertook semistructured interviews with over 40 women participants in the training programme hosted by the National Council for Women's political empowerment programme. A series of semistructured interviews were conducted by the author, Zeinab and Sawsan, with various stakeholders: Dr Mahmoud Sherif, Director of the political empowerment programme, programme officers responsible for the training programme, as well as leading members of different political parties and forces and NGO activists in Cairo and Upper Egypt. A review of press articles, training material and scholarly and grey literature in both Arabic and English was undertaken by the author to complement the primary data. Finally, many thanks to Ms Mona Bakr whose exceptional coordination and management skills were key in making this initiative materialise.

1 Hawanim is the plural of hanim, an Arabic word that means a woman of aristocratic or upper class, or Lady. Garden City is an upper class residential suburb in the heart of Cairo, historically (and to this day), known to be help in mobilising public opinion against it. It is also important to encourage the emergence of a feminist caucus in parliament, an extremely important collective political actor in many other country contexts. Some pathways may not have women candidates as their focus, but may be equally important in creating the enabling environments for them, and for future generations of women activists such as revitalising the feminist movement in Egypt in order to play a more forceful role in influencing the debates on political empowerment. Finally, it cannot be stressed enough that pathways of political power are trodden in sociopolitical and economic contexts whose dynamics are critical for how the intersection of gender, class, religion and political orientation play out.

home to the members of the aristocratic or upper class.

2 Shortly after, businesswoman Shahinaz el Naggar resigned as MP for el Manial district, after she married business tycoon Ahmed Ezz, thus reducing the number of women in parliament to eight.

3 Because of the sensitivity of the subject matter, the identity of the interviewee has been kept anonymous here.

4 Interview, October 2009.

5 One of Egypt's oldest political parties; was in power for several terms prior to the 1950s.

6 Interview, October 2009.

7 Interview, October 2009.

8 The Muslim Brotherhood announced their party platform in 2008; however, they refused to submit an official registration application for the establishment of a political party because, they explained, of its inevitable rejection by a partisan political parties committee.

9 Interview, January 2009.

$10 \mathrm{An}$ article discussing the findings of the research on the training programme provided by the National Council for Women as well as other NGOs, their nature and the profile of women who participate in them, and perceptions of the role these initiatives play in women's political paths is explored in an in-depth manner in a forthcoming paper by the author.

11 For the most part, there are of course women running as independents and less frequently so as members of the opposition parties, who have significant financial means. However, criteria can be established in order to support women who need help in a non-partisan manner. 


\section{References}

Al-Akhbar (2010) 'Suzanne Mubarak asks Women to Prove their Capabilities Through Parliamentary Seats' (no author) [in Arabic] 31 May: 4

El Borai, Negad (2000) 'Assessment of the Performance of Women in Elected Legislatures: Twenty Years of Parliamentary Work', paper presented at the Conference on Allocating Quotas in Legislatures, Ain Shams University, Cairo, Egypt [in Arabic]

El Naqash, Fareida (2000) 'My Experience in the Elections when I was Fielded', paper presented at the Conference on Allocating Quotas in Legislatures, Ain Shams University, Cairo, Egypt [in Arabic]

El Sawi, Ali (2008) Political Empowerment for the Arab Woman: A Study of the Role of Parliament in Egypt, Jordan and Bahrain, Jordan: UNIFEM [in Arabic]

Marei, Afaf (ed.) (2009) Second Shadow Report of The CEDAW Coalition, Cairo: Egyptian Association for Community Participation Enhancement (EACPE)
Ottaway, Marina (2003) Democracy Challenged. The Rise of Semi-Authoritarianism, Washington DC: Carnegie Endowment for International Peace Ouf, Eman, (2010) 'Egyptian Women Against the Quota', Al-Mal 21 February: 9 [in Arabic]

Schedler, A. (2006) Electoral Authoritarianism: The Dynamics of Unfree Competition, Boulder: Lynne Reinner Publishers: 3

Shuman, Mohammed (2000) 'Democratic Reform and the Workers and Farmers Quota', paper presented at the conference on

Allocating Quotas in Legislatures, Ain Shams University, Cairo, Egypt [in Arabic]

Tadros, M. (2010) 'Egypt Country Study' in Freedom House Women's Rights in the Middle East and North Africa, http://freedomhouse.org/ template.cfm?page $=384 \& \mathrm{key}=253 \&$ parent $=$ $24 \&$ report $=86$

Zahran, Farid (ed.) (2008) Report on the Egyptian Parliamentary Elections, Cairo: Al Mahroussa [in Arabic] 